\title{
Comprehensive Report to Congress Clean Coal Technology Program
}

\section{Confined Zone Dispersion \\ Low-NOxFlue Gas Desulfurization Demonstration}

\section{A Project Proposed By: Bechtel Corporation}

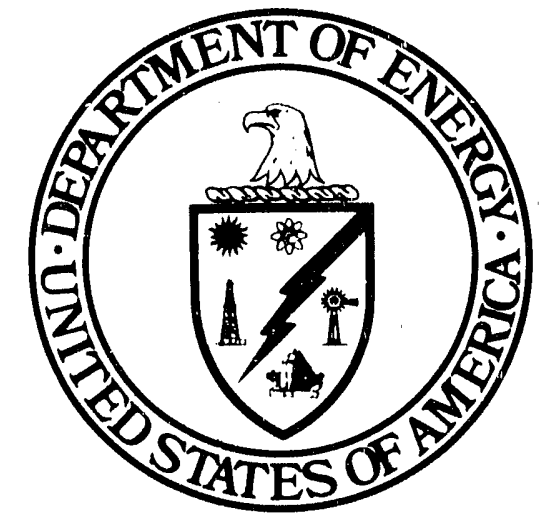

\footnotetext{
U.S. Department of Energy Assistant Secretary for Fossil Energy Office of Clean Coal Technology Washington, D.C. 20585
} 


\section{IABLE OF CONTENTS}

Page

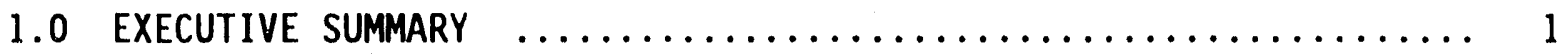

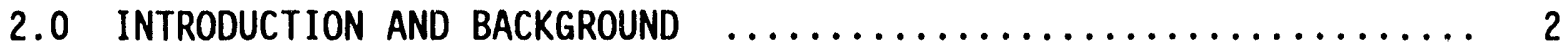

2.1 Requirement for Report to Congress $\ldots \ldots \ldots \ldots \ldots \ldots \ldots . \ldots 2$

2.2 Evaluation and Selection Process $\ldots \ldots \ldots \ldots \ldots \ldots \ldots \ldots, 4$

2.2.1 PON Objective .......................... 4

2.2.2 Qualification Review $\ldots \ldots \ldots \ldots \ldots \ldots \ldots \ldots, 4$

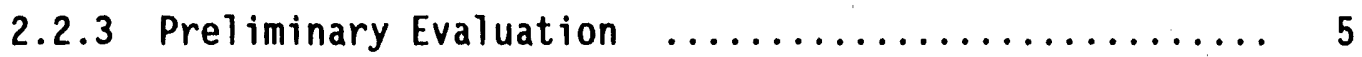

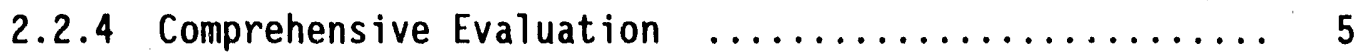

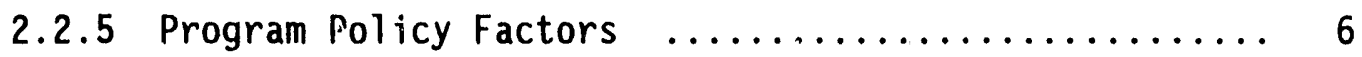

2.2.6 Other Considerations $\ldots \ldots \ldots \ldots \ldots \ldots \ldots \ldots \ldots, 7$

2.2.7 National Environmental Policy Act (NEPA) Compliance $\ldots . . . \ldots \ldots \ldots \ldots \ldots \ldots \ldots \ldots, 7$

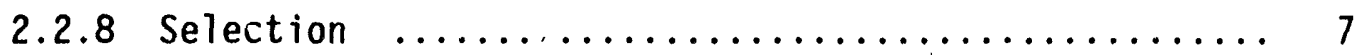

3.0 TECHNICAL FEATURES $\ldots \ldots \ldots \ldots \ldots \ldots \ldots \ldots \ldots \ldots \ldots \ldots \ldots \ldots \ldots \ldots \ldots$

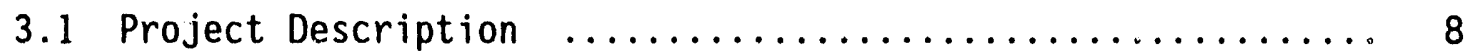

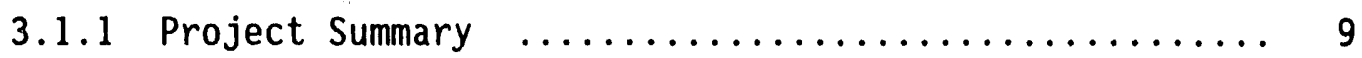

3.1.2 Project Sponsorship and Cost $\ldots \ldots \ldots \ldots \ldots \ldots, 9$

3.2 CZD-FGD Process ............................... 10

3.2.1 Overview of Process Development $\ldots \ldots \ldots \ldots \ldots \ldots, 10$

3.2 .2 Process Description ...................... 11

3.2.3 Application of Process in Proposed Project ........ 14

3.3 General Features of the Project $\ldots \ldots \ldots \ldots \ldots \ldots \ldots \ldots . \ldots \ldots$

3.3.1 Evaluation of Developmental Risk .............. 15

3.3.1.1 Similarity of Project to Other Demonstration/Commercial Efforts ........ 15

3.3.1.2 Technical Feasibility $\ldots \ldots \ldots \ldots \ldots \ldots . \ldots 16$

3.3.1.3 Resource Availability ............... 17

3.3.2 Relationship Between Project Size and Projected Scale of Commercial Facility .......... 17 


\section{TABLE OF CONTENTS}

Page

3.3.3 Role of the Project in Achieving Commercial Feasibility of the Technology $\ldots \ldots \ldots \ldots \ldots \ldots . .18$

3.3.3.1 Applicability of the Data to be Generated ........................ 18

3.3.3.2 Identification of Features that Increase Potential for Commercialization ......... 19

3.3.3.3 Comparative Merits of Project and Projection of Future Commercial Economic and Markét Acceptability ....... 19

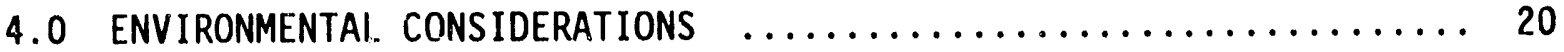

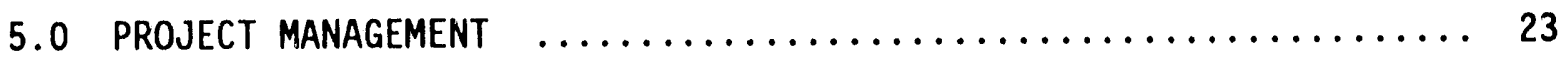

5.1 Overview of Management Organization $\ldots \ldots \ldots \ldots \ldots \ldots \ldots, 23$

5.2 Identification of Respective Roles and Responsibilities ............................ 23

5.3 Project Implementation and Control Procedures $\ldots \ldots \ldots \ldots 25$

5.4 Key Agreements Impacting Data Rights, Patent Waivers, and Information Reporting $\ldots \ldots \ldots \ldots \ldots \ldots \ldots 26$

5.5 Procedures for Commercialization of Technology $\ldots \ldots \ldots .28$

6.0 PROJECT COST AND EVENT SCHEDULING $\ldots \ldots \ldots \ldots \ldots \ldots \ldots \ldots \ldots . \ldots \ldots$

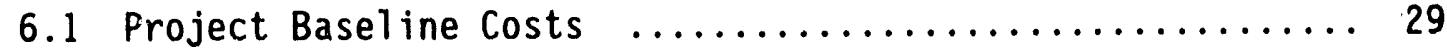

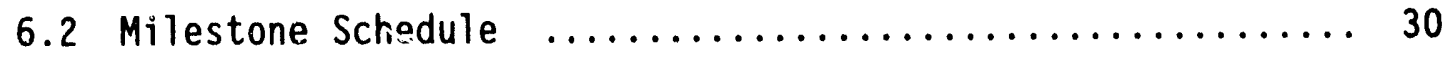

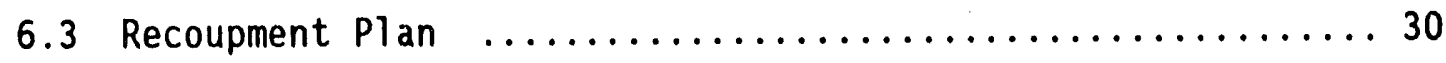




\subsection{EXEC.UTIVE SUMMARY}

In September 1988, Congress provided $\$ 575$ million to conduct cost-shared Clean Coal Technology (CCT) projects to demonstrate technologies that are capable of retrofitting or repowering existing facilities. To that end, a Program Opportunity Notice (PON) was issued by the Department of Energy (DOE) in May 1989, solicitirig proposals to demonstrate innovative energy efficient technologies that were capable of being commercialized in the 1990s, and were capable of (1) achieving significant reductions in the emissions of sulfur dioxide and/or the oxides of nitroger from existing facilities to minimize environmental impacts such as transboundary and interstate pollution and/or (2) providing for future energy needs in an environmentally acceptable manner.

In response to the PON, 48 proposals were received in August 1989. After evaluation, 13 projects were selected in December 1989 as best furthering the goals and objectives of the PON. The projects were located in 10 different states and represented a variety of technologies. A proposal by Airpol, Inc. was one of those selected for negotiation.

One of the thirteen projects selected for funding is a project proposed by Bechtel Corporation to demonstrate the Confined Zone Dispersion Flue Gas Desulfurization (CZD-FGD) process. This project will demonstrate the removal of $\mathrm{SO}_{2}$ from the flue gas of a utility coal-fired boiler retrofitted with the CZDFGD process.

In the CZD-FGD process, a finely atomized slurry of a highly reactive pressure hydrated dolomitic lime is sprayed into the flue gas stream between the boiler air heater(s) and the particulate collection equipment. The lime slurry is injected into the center of the duct and the type and position of the spray nozzles are designed to produce a cone of fine spray. As the cone of spray moves downstream and expands, the gas within the cone cools and the $\mathrm{SO}_{2}$ is rapidly absorbed by the liquid droplets. The spray droplets mix with the hot flue gas and dry very rapidly. This fast drying time precludes wet particle build-up in the duct and allows carry-over of the dry reaction products and the unreacted lime in the flue gas, which will be removed by the particulate collection equipment. 
The CZD-FGD process is expected to remove $50 \%$ of $\mathrm{SO}_{2}$ emissions from coal fired boilers. It is applicable to every size of industrial and utility boiler and is particularly suited for retrofit applications where it is necessary to reduce annual $\mathrm{SO}_{2}$ emissions. If successfulily demonstrated, this project would establish an alternative process technology to conventional wet and dry flue Gas Desulfurization (FGD) processes while requiring less physical space and lower capital and operating and maintenance costs.

The project will be conducted at the 147 megawatt electric (MWe) coal fired Seward Station Unit No.15, owned by Pennsylvania Electric Company. This plant is located in Seward, Pennsylvania, as shown in Figure 1, and is presently in commercial operation. Pennsylvania bituminous coal (approximately 1.2 to $2.5 \%$ sulfur) will be used in the project.

This demonstration project will be performed over a 37-month period. Project activities include design, permitting, procurement, fabrication, construction, parametric and long term cesting, data analysis, site restoration and reporting of results. Field testing is scheduled to begin in mid-1991. Overall project completion is scheduled to occur in mid-1993.

The total project cost is $\$ 9,211,600$. The co-funders are DOE $(\$ 4,605,800)$ Bechtel Corporation $(\$ 761,186)$, Pennsylvania Electric Company $(\$ 2,971,389)$, Pennsylvania Energy Development Authority $(\$ 750,000)$, New York State Electric \& Gas Corporation $(\$ 100,000)$, and Rockwell Lime Company $(\$ 23,225)$.

\subsection{INTRODUCTION AND BACKGROUND}

\subsection{Requirement for a Report to Congress}

On September 27, 1988, Congress made available funds for the third clean coal demonstration program (CCT-III) in Public Law 100-446, "An Act Making Appropriations for the Department of the Interior and Related Agencies for the Fiscal Year Ending September 30, 1989, and for Other Purposes" (the "Act"). Among other things, this Act appropriates funds for the design, construction, and operation of cost-shared, clean coal projects to demonstrate the feasibility of future commercial applications of such "... technologies capable of retrofitting or repowering existing facilities ...." On June 30, 1989, Public Law 101-45 was signed into law, requiring that CCT-III projects be selected no later than January 1, 1990. 


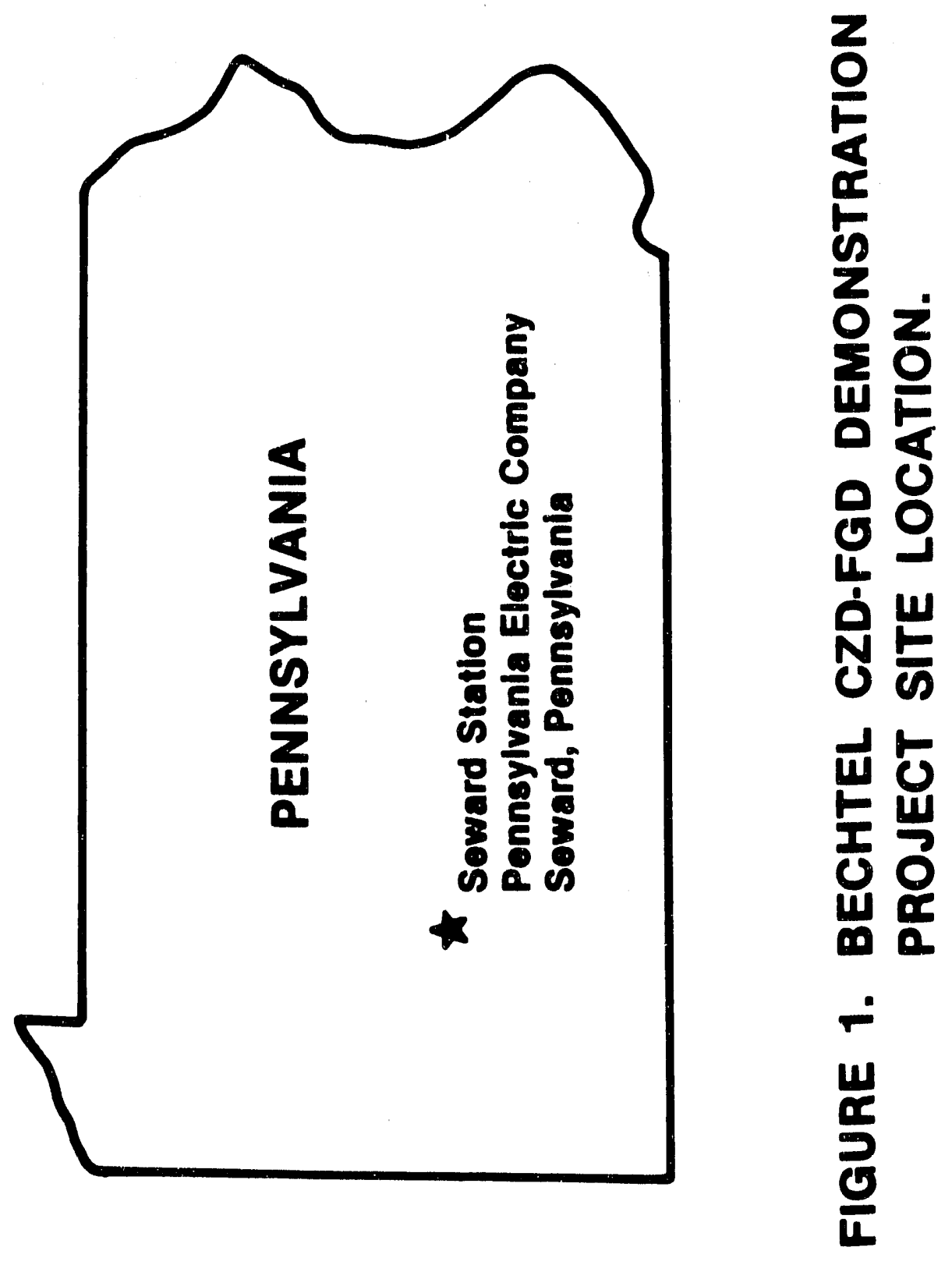


Public Law 100-446 appropriates a to'al of $\$ 575$ million for executing CCT-III. of this total, $\$ 6.906$ million are required to be reprogrammed for the Small Business and Innovative Research Program. (SBIR) and $\$ 22.548$ million are designated for Program Direction Funds for costs incurred by DOE in implementing the CCT-III program. The remaining, $\$ 545.546$ million was available for award under the PON.

The purpose of this Comprehensive Report is to comply with Public Law 100-446, which directs the Department to prepare a full and comprehensive report to Congress on each project selected for award under the CCT-III Program.

\subsection{Evaluation and Selection Process}

DOE issued a draft PON for public comment on March 15, 1989, receiving a total of 26 responses from the public. The final PON was issued on May 1, 1989, and took into consideration the public comments on the draft PON. Notification of its availability was published by DOE in the Federal Register and the Commerce Business Daily on March 8, 1989 . DOE received 48 proposals in response to the CCT-III solicitation by the deadline, August 29, 1989.

\subsubsection{PON Objective}

As stated in PON Section 1.2, the objective of the CCT-III solicitation was to obtain "proposals to conduct cost shared Clean Coal Technology proiects to demonstrate innovative, energy efficient technologies that are capable of being commercialized in the 1990s. These technologies must be capable of (1) achieving significant reductions in the emissions of sulfur dioxide and/or the oxides of nitrogen from existing facilities to minimize environmental impacts such as transboundary and interstate pollution and/or (2) providing for future energy needs in an environmentally acceptable manner."

\subsubsection{Qualification Review}

The PON established seven Qualification Criteria and provided that, "In order to be considered in the Preliminary Evaluation Phase, a proposul must successfully pass qualification." The Qualification Criteria were as follows: 
(a) The proposed demonstration project or facility must be located in the United States.

(b) The proposed demonstration project must be designed for and operated with coal(s) from mines located in the United States.

(c) The proposer must agree to provide a cost share of at least 50 percent of total allowable project cost, with at least 50 percent in each of the three project phases.

(d) The proposer must have access to, and use of, the proposed site and any proposed alternate site(s) for the duration of the project.

(e) The proposed project team must be identified and firmly committed to fulfilling its proposed role in the project.

(f) The proposer agrees that, if selected, it will submit a "Repayment Plan" consistent with PON Section 7.4.

(g) The proposal must be signed by a responsible official of the proposing organization authorized to contractually bind the organization to the performance of the Cooperative Agreement in its entirety.

\subsubsection{Preliminary Evaluation}

The PON provided that a Preliminary Evaluation would be performed on all proposals that successfully passed the Qualification Review. In order to be considered in the Comprehensive Evaluation phase, a proposai must be consistent with the stated objective of the PON, and must contain sufficient business and management, technical, cost, and other information to permit the Comprehensive Evaluation described in the solicitation to be performed.

\subsubsection{Comprehensive Evaluation}

The Technical Evaluation Criteria were divided into two major categories: (1) the Demonstration Project Factors were used to assess the technical feasibility and likelihood of success of the project, and (2) the Commercialization Factors were used to assess the potential of the proposed technology to reduce emissions from existing facilities, as well as to meet future energy needs through the 
environmentally acceptable use of coal, and the cost effectiveness of the proposed technology in comparison to existing technologies.

The Business and Management criteria required $:$ Funding $\mathrm{Pl}$ an and an indication of Financial Commitment. These were used to determine the business performence potential and commitment of the proposer.

The PON provided that the Cost Estimate would be evaluated to determine the reasonableness of the proposed cost. Proposers were advised that this determination "will be of minimal importance to the selection," and that a detailed cost estimate would be requested after selection. Proposers were cautioned that if the total project cost estimated after selection is greater than the amount specified in the proposal, DOE would be under no obligation to provide more funding than had been requested in the proposer's Cost Sharing Plan.

\subsubsection{Program Policy Factors}

The PON advised proposers that the following program policy factors could be used by the Source Selection Official to select a range of projects that would best serve program objectives:

(a) The desirahility of selecting projects that collectively represent a diversity of methods, technical approaches, and applications.

(b) The desirability of selecting projects in this solicitation that contribute to near term reductions in transboundary transport of pollutants by producing an aggregate net reduction in emissions of sulfur dioxide and/or the oxides of nitrogen.

(c) The desirability of selecting projects that collectively utilize a broad range of U.S. coals and are in locations which represent a diversity of EHSS, regulatory, and climatic conditions.

(d) The desirability of selecting projects in this solicitau, sh that achieve a balance between (1) reducing emissions and transboundary pollution and (2) providing for future energy needs by the environmentally acceptable use of coal or coal-based fuels. 
The word "collectively" as used in the foregoing program policy factors, was defined to include projects selected in this solicitation and prior clean coal solicitations, as well as other ongoing demonstrations in the United States.

\subsubsection{Other Considerations}

The PON provided that in making selections, Dol: would consider giving preference to projects located in states for which the rate-making bodies of those states treat the Clean Coal Technologies the same as pollution control projects or technologies. This consideration could be used as a tie breaker if, after application of the evaluation criteria and the program policy factors, two projects receive identical evaluation scores and remain essentialiy equal in value. This consideration would not be applied if, in doing so, the regional geographic distribution of the projects selected would be altered significantly.

\subsubsection{National Environmental Policy Act (NEPA) Compliance}

As part of the evaluation and selection process, the Clean Coal Technology Program developed a procedure for compliance with the National Environmental Policy Act of 1969 (NEPA), the Council or. Environmental Quality regulations for implementing NEPA (40 CFR 1500-1508) and the DOE guidelines for NEPA compliance with NEPA (52 FR 47662, December 15, 1987).

This procedure included the publication and consiceration of a publicly available Final Programmatic Environmental Impact Statenent (DOE/EIS-0146) issued in November 1989, and the preparation of confidential preselection project-specific environmental reviews for internal DOE use. DOE al so prepares publicly available site-specific documents for each selected demonstration project as appropriate under NEPA.

\section{2 .8 Selection}

After considering the evaluation criteria, the program policy factors, and the NEPA strategy as stated in the PON, the Source Selection Official selected 13 projects as best furthering the objectives of the CCT-III PON. 
Secretary of Energy, Admiral James D. Watkins, U.S. Navy (Retired), announced the selection of 13 projects on December 21,1989 . In his press briefing, the Secretary stated he had recently signed a DOE directive seiting a 12 month deadline for the negotiation and approval of the 13 cooperative agreements to be awarded under the CCT-III solicitation.

\subsection{TECHNICAL FEATURES}

\subsection{Project Description}

The Bechtel Confined Zone Dispersion Flue Gas Desulfurization (CZD-FGD) project will demonstrate that lime slurry flue gas duct injection is an economical means of reducing the acid rain precursor $\left(\mathrm{SO}_{2}\right)$ from utility boilers. The process is particularly suited for retrofitting onto existing botlers.

The primary advantage of the CZD-FGD process over conventional poilution control processes is the removal of $\mathrm{SO}_{2}$ within boller ductwork. This eliminates the need for separate pieces of equipment for pollutant removal and minimizes the pollution control equipment space requirements, thereby making it easy to integrate the process into existing power plant facilities. In addition, capital and operating and maintenance (O\&M) costs are projected $t$ ) be substantially lower then conventional wet and dry FGD processes.

The demonstration will be conducted at Pennsylvania Electric Company's (Penelec's) Seward Station Unit No. 15. This boiler is a 147 MW coal fired unit, which utilizes Pennsylvania bituminous coal (approximately 1.2 to $2.5 \%$ sulfur). One of the two flue gas ducts leading from the boiler will be retrofitted with the CZD-FGD technology. This size demonstration is large enough to provide test results representative of a utility retrofit, yet small enough to be economical.

The goal of this program is to prove the technical and economic feasibility of the CZII-FGD technology on a commercial scale. If successful, the process will achie, $50 \% \mathrm{SO}_{2}$ removal at lower capital and 0\&M costs than other systems. 


\subsubsection{Project Summary}

Project Title:

Confined Zone Dispersion Flue Gas Desulfurization Demonstration

Proposer:

Bechtel Corporation

Project Location:

Seward (Seward Station)

Indiana County, Pennsylvania

Technology:

Flue Gas Cleanup by Lime Slurry Duct Injection

Application:

Retrofit of Coal Fired Industrial and Utility Boilers

Types of Coai Used:

Pennsylvania Bituminous Coal (1.2 to 2.5\% Sulfur)

Product:

Environmental Control Technology

Project Size:

73.5 MWe (Half of Unit No. 15)

Project Start Date:

June 1,1990

Project End Date:

July 1,1993

\subsubsection{Project Sponsorship and Cost}

Project Sponsor: Bechtel Corporation

Co-Funders: Pennsylvania Electric Company, Pennsylvania Energy Development Authority, New York State Electric \& Gas Corporation and Rockwell Lime Company

Estimated Project Cost: $\$ 9,211,600$

Distribution:

Participant

Share (\%)

50
DOE

Share (\%) 


\subsection{CZD-FGD Process}

\subsubsection{Overview of Process Development}

In the mid 1970s, Bechtel selected a form of the old Battersea calcium based throwaway FGD process for further development at the EPA Shawnee test facility, and for about the next ten years, directed the test operations of the facility. During this time Bechtel and many others working in this area recognized the need to increase the reactivity of the system and found that physically pretreating (converting limestone to $l$ ime) the reagent made it more reactive.

In the late 1970s, Bechtel's FGD Research and Engineering Development staff found that further physical pretreatmunt (pressure hydration) would produce a low cost calcium based reagent consisting of a slurry of very small lime particles with extremely high surface area. Since pressure hydrated dolomitic lime made from dolomitic limestone (i.e. limestone containing approximately equal parts of calcium and magnesium) was commercially available as plaster and stucco, it became an obvious choice for use in the Colstrip No. 3 and 4 units being built for Montana Power Company. This rocess became known as the Type $S 1$ ime wet scrubbing system and is presently still in operation with $\mathrm{SO}_{2}$ removals in excess of $95 \%$.

At the same time, other developers became interested in spray-dry FGD systems. These systems use essentially the same wet chemistry as wet scrubbing systems, but spray the slurry into a reacior vessel that is designed so that the droplets evaporate to dryness before inpinging on the wall of the downstream surfaces. This approach allowed the chemical reaction to proceed for a maximum of ten seconds, which resulted in poor lime utilization. To resolve this problem, solids recirculation was used. This process is analogous to lime recirculation that occurs in a wet scrubbing system. Solids recirculation, however, increases operational and maintenance costs.

To avoid these problems and to achieve high reagent reactivity, Bechtel substituted hydrated lime with Type $s$ dolomitic lime, and successfully tested its use in a small pilot plant. 
The above described systems were developed to remove high percentages of $\mathrm{SO}_{2}$. Since that time, State and Federal regulations limiting $\mathrm{SO}_{2}$ emissions have created a potential market for economic retrofit of FGD systems that remove only about $50 \%$ of the contained $\mathrm{SO}_{2}$. As a result, Bechtel developed the CZD-FGD process.

Bechtel's CZD-FGD process was selected by DOE for proof-of-concept (POC) testing at a 5 MWe scale. These initial tests were performed in 1986 using a slipstream of flue gas from Consumers Power Company's 260 MWe J. H. Campbell Station Unit No. 1. The results of inese $t \in$ sts showed that $\mathrm{SO}_{2}$ removal in excess of $50 \%$ were achieved using either pressure hyourated dolomitic lime (PHDL) or calcitic lime $(C L)$. In addition, the process did not cause any undue corrosion in the flue gas duct downstream of the injection point or in the electrostatic precipitator. Following these tests, large scale POC tests were performed at Penelec's Seward Station linit No. 15, where the CZD-FGD system was retrofitted to one of two parallel flue gas ducts. The Seward tesining was initially supported by Bechtel, Penelec, and the Pennsylvania Energy Development Authority (PEDA). DOE and New England Power Service provided additional support to extend the testing. The results of the large scale POC tests confirmed that a true confined zone could be obtained and that duct deposits could be prevented by limiting injection rates. The short distance between the iniertion point and the duct turning vanes limited the quantity of lime slurry that could be injected into the duct and consequently limited the percent of $\mathrm{SO}_{2}$ removal.

\subsubsection{Process Description}

The CZD-FGD process, shown schematically in Figure 2, involves the injection of PHDL into the flue gas ductwork located between a boilers' air heater's) and particulate removi 1 equipment. The lime can be pressure hydrated by the supplier and shipped to the site, as shown in Figiire 3 , or it can be pressure hydrated on-site, as shown in Figure 2. The decision to purchase pressure hydrated lime oir to jiressure hydrate quistlime on-site is a matter of economics. On-site pressure hydration is generally more econonical for large units and for those burning high sulfur coal. 


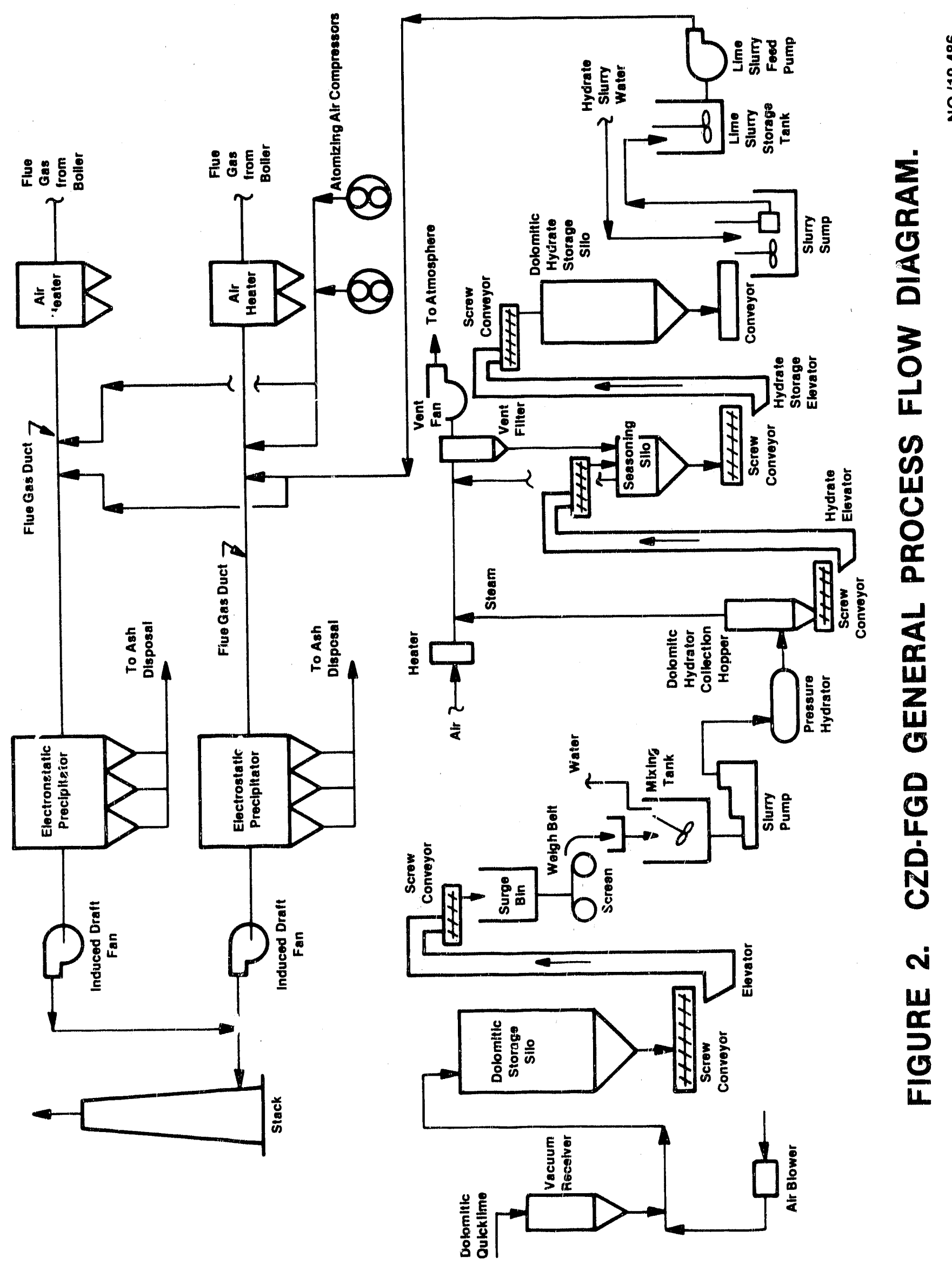




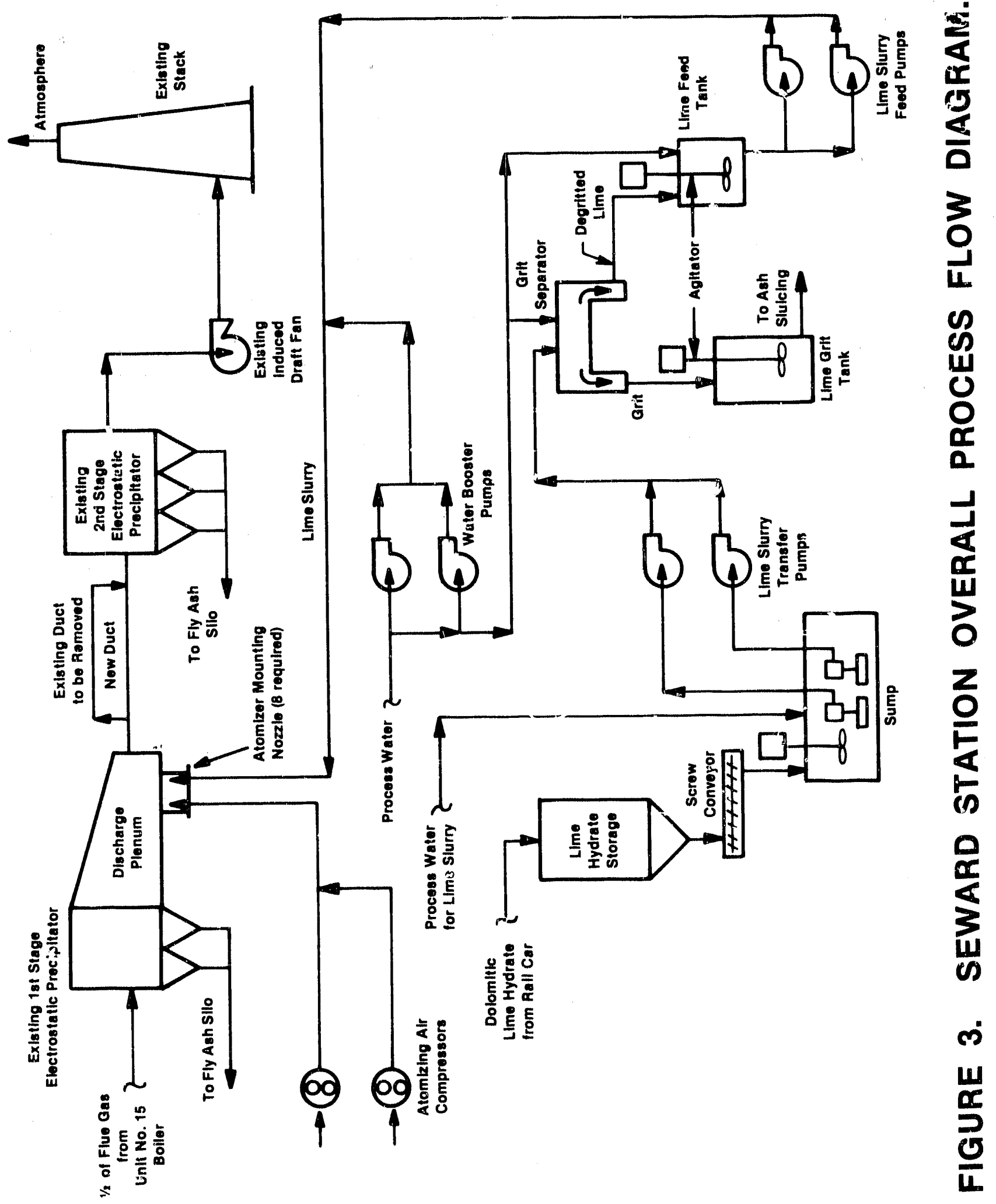


The removal of $\mathrm{SO}_{2}$ in the CZD-FGD process is based on the principle that, in the presence of water, $\mathrm{SO}_{2}$ from the flue gas will be absorbed as sulfurous acid and if exposed to lime will react instantaneously to produce calcium and magnesium sulfites and sulfates, which then can be removed by the downstream particulate removal equipment. In the CZD-FGD process, the wet reaction particles and unreacted lime must dry before contacting the duct, turning vanes, electrostatic precipitator, etc. or they will adhere to these surfaces and cause unwanted deposit build-ups which will affect operation. The CZD-FGD process precludes this from occurring by injecting the prepared lime slurry close to the center of the flue gas duct, parallel to the flow of gas. By using narrow angle sprays and carefully positioning the atomizers, it is possible to obtain a wet zone in the middle of the duct for $\mathrm{SO}_{2}$ removal while maintaining an envelope of hot gas between the wet zone and the duct walls, which is the principle of the confined zone. As the cone of spray moves downstream and expands, the gas within the cone cools and its $\mathrm{SO}_{2}$ is rapidly absorbed by the liquid droplets. The spray droplets on the outside of the cone mix with the hot gas and dry very rapidly. Using the proper slurry concentration and injection rate, drying will be complete before the droplets contact the walls of the duct. At a certain distance downstream of the injection point, the free moisture in the spray will completely evaporate and the dry solids can contact the duct and the turning vanes and will not adhere to them. The dry reaction particles and the unreacted lime are then removed by the particulate removal equipment along with the fly ash.

\subsubsection{Application of Process in Proposed Project}

The Seward Station Unit No. 15 boiler is a nominal 147-MW pulverized coal fired boiler with two flue gas ducts. Each duct connects first stage and second stage electrostatic precipitator modules, which are located downstream of the air heaters. The installation of the CZD-FGD system will require that the west duct be replaced with a 110 foot long straight duct that will permit a lime slurry retention time of two seconds and that additional atomizers be added.

The specific objectives of the CZD-FGD demonstration are to (1) achieve at least $50 \% \mathrm{SO}_{2}$ removal with up to $50 \%$ alkali utilization, (2) demonstrate that $\mathrm{SO}_{2}$ removal costs of below $\$ 300 /$ ton $\mathrm{SO}_{2}$ removed are achievable, and (3) demonstrate that the process has no negative effects on normal boiler operation, and no increase in particulate emissions and percent opacity. 


\subsection{General Features of the Project}

\subsubsection{Evaluation of Developmental Risk}

As described earlier, much prior work has been performed on the process. The basic principles of the process are similar to other commercially available technologies. In addition, the lime is commercially available and the lime hydration, handling and slurry injection systems have been commercially demonstrated. Furthermore, bench scale, pilot scale and full scale development work by Bechtel has been successful and indicates that further large scale testing is warranted.

There is some risk that the collection efficiency of the electrostatic precipitator may decrease due to the increase in the particulate matter in the flue gas. This is considered to be a low risk, because the cooling of the flue gas and the addition of water vapor from the lime slurry injection should condition the gas and improve the performance of the precipitator. Further, if necessary, other methods of improving precipitator performance, such as, additives, improved rapping and improved automatic voltage control can be tested and used.

\subsubsection{Similarity of the Project to Other Demonstration/Cominercial Efforts}

The CZD-FGD process is similar to several other processes. In 1985, DOE awarded POC pilot plant test contracts not only to Bechtel, but also to General Electric (GE) and Dravo. GE's demonstration involved the injection of calcitic lime slurry through a rotary atomizer into a vertical and a horizontal duct. The results of the tests, however, were inconclusive.

Dravo's demonstration involved the injection of dry calcitic lime into a duct followed or preceded by water atomization in the duct. As with the GE demonstration, the results were inconclusive.

The Babcock \& Wilcox Company (B\&W), through funding from DOE, is presently testing two technologies similar to the Bechtel CZD-FGD technology. The first is the Coolside sulfur capturing process, which consists of injecting a form of lime into the combustion gases at the end of ductwork leading from a boiler. The sulfur in the flue gas reacts with the lime and is converted to solid particles, which are collected by the downstream particulate removal equipment. 
In this $105 \mathrm{MW}$ demonstration project by $B \& W / C O N S O L$ at Edgewater in Ohio, the flue gas will be sprayed with water to improve the effectiveness of the lime and the performance of the electrostatic precipitator.

The second technique being tested by B\&W is the LIMB process, where the sorbent is injected into the upper part of the combustion zone. As with the coolside process, the sulfur is captured by the downstream particulate removal equipment and removed with the fly ash.

Another technology, the Gas Reburning-Sorbent Injection (GR-SI) process is being demonstrated at two sites as part of a clean coal technology project. One site is the City Water Light and Power Company's Lakeside Station located at Springfield, Illinois where the process is being demonstrated on a 33 MWe cyclone-fired boiler. The other site is the Illinois Power Company's Hennepin Station, located at Hennepin, Illinois where the process is being demonstrated on an 80 MWe tangentially fired unit. The GR-SI technology combines gas reburning with sorbent injection. In the GR-SI process, the sorbent is injected into the furnace.

The Gas Suspension Absorption (GSA) process is being demonstrated in the Clean Coal Technology Program's third round. In this technology, the sorbent is injected near the base of the absorber and carried upward to a cyclone where some of the sorbent is removed from the flue gas. The balance of the sorbent is recovered by a baghouse or electrostatic precipitator. The bulk of the recovered sorbent is recycled, as a dry solid, to the process and the balance is sent to disposal. Fresh sorbent is injected into the base of the absorber as a slurry. The sorbent content of the slurry is controlled by the concentration of $\mathrm{SO}_{2}$ in the flue gas and the water content is controlled to obtain the optimum flue gas temperature. The developer of the GSA process claims that $90 \% \mathrm{SO}_{2}$ removal can be expected.

\subsubsection{Technical Feasibility}

The CZD-FGD process has been under development since the early 1980s. The technology has undergone bench scale tests, POC pilot plant tests, and POC large commercial unit tests and has been patented by Bechtel. The results of the research performed to date indicate that the $73.5 \mathrm{MW}$ scale demonstration is required to obtain the necessary additional data for commercialization of the technology. 


\subsubsection{Resource Availability}

A11 resources are available for this project over the 37 -month demonstration period.

The demonstration will not impact the quantity of coal presently being utilized at the Seward Station Unit No. 15, however, during parametric testing higher sulfur coal than normally used will be required to verify the effect of the absorbents on $\mathrm{SO}_{2}$ removal. In addition, the demonstration will utilize different types of absorbents, such as dolomitic and calcitic lime. The availability of these raw materials is anticipated to be adequate not only for the demonstration, but also for commercialization of the technology.

This program involves a pre-NSPS boller installation. The unit has a fully operational steam-boller and turbine-generator set with appropriate facilities and scheduling flexibility to accommodate this project. The site selected for the proposed demonstration will provide an excellent opportunity to evaluate the technology in essentially all of the situations that are likely to be encountered in the commerctalization of the technology. All appropriate resources such as, coal, sorbent, etc. can be made available to the site. In addition, adequate funds have been committed by the co-funders to cover their share of the estimated project costs.

\subsubsection{Relationship Between Project Size and Projected Scale of Commercial Facility}

As mentioned previously, the test boller is a $147 \mathrm{MW}$ utility unit, with two flue gas ducts, each serving a capacity equivalent to $73.5 \mathrm{MW}$. Each duct has a crosssectional area of 88 square feet. The commercial applications vary in size from about $80 \mathrm{MW}$ with two ducts to about $860 \mathrm{MW}$ with three ducts. The smaller units are about one half the size of the test boiler and the larger units are about four to six times larger, with duct cross-sections varying between 48 and 352 square feet.

The critical parameters involved in this technology are the maximum volume of slurry that can be injected per square foot of duct cross-section without causing deposition in the duct, the length of duct required for evaporation of the atomized slurry, and the inlet flue gas temperature. The first two parameters are dependent on boiler and duct size, but can be directly scaled up or down. The third parameter, inlet flue gas temperature, is independent of boiler or duct 
size. Once these parameters are determined during the demonstration, they can be directly applied to any boiler size.

The risk of scale-up is considered to be minimal and the demonstration is expected to prove the applicability of the CZD-FGD technology for retrofit on pre-NSP; bollers without further demonstration.

\subsubsection{Role of Project in Achieving Commercial Feasibility of the Technology.}

This project will demonstrate, at utility scale, a new flue gas clean-up technology for the removal of acid rain causing emissions. This technology is particularly suited to existing units that may be required to comply with new environmental legislation. The technology has been tested at bench, pilot and full scale. The commercialization of the technology, however, requires further comprehensive testing to confirm previous test results. The suitability of the CZD-FGD process for retrofit to utility boilers will be fully established when it is demonstrated that significant amounts of $\mathrm{SO}_{2}$ can be removed from flue gas at less capital and $0 \& M$ costs than current flue gas clean-up technologies.

\subsubsection{Applicability of the Data to be Generated}

Al1 pertinent data will be recorded, collected, analyzed and reported. Measurements that will be taken during the demonstration include flue gas inlet and outlet temperatures, $\mathrm{SO}_{2} / \mathrm{NO}_{x} / \mathrm{O}_{2}$ inlet and outlet concentrations, lime slurry rate and pressure, lime slurry concentration, compressed air pressure and flow rate, electrostatic precipitator characteristics, duct temperatures, and atomizer position and flow rate.

Different types of $\mathrm{SO}_{2}$ absorbents will be tested during the demonstration along with high and low sulfur coal to determine the effects of $\mathrm{SO}_{2}$ concentration on percent $\mathrm{SO}_{2}$ removal, lime utilization and electrostatic precipitator performance. Selected additives for improving $\mathrm{SO}_{2}$ removal and electrostatic precipitator particulate emissions will also be tested.

The analyses to be performed will include calculations for $\mathrm{SO}_{2}$ removal and 1 ime utilization and notation of recorded data indicating stack opacity with and without additives and conditioning agents. 
Economic assessments $\mathrm{Will}_{1}$ be performed by comparing the cost per ton of $\mathrm{SO}_{2}$ removed by this CZD-FGD process with the currently available commercial technology options.

\subsubsection{Identification of Features that Increase Putential for Commercialization}

Once commercially proven the CZD-FGD process will provide an economical and technically acceptable means for the removal of $\mathrm{SO}_{2}$. The minimal space requirements and the competitive capital and 0\&M costs make this technology attractive for retrofit applications for utility and industrial coal-fired botlers. The CZD-FGD process consists large y of proven, commercially avallable equipment, such as, ductwork, atomi:iers, air compressors, tanks, pumps, etc.

If the demonstration project is successful, the following factors should assure commercialization.

- Removal of $50 \% \mathrm{SO}_{2}$

- Lower capital cost and total cost per ton of $\mathrm{SO}_{2}$ removed

- Less site space requirements than for conventional flue gas cleanup technologies

- Easy to retrofit

- No increase in flue gas pressure drop and therefore, no need to add booster fans or modify existing induced draft fans

- Formation of dry, free flowing, non-toxic reaction products, which are removed by the downstream particulate control equipment and easily disposed of with the rest of the fly ash

$0 \quad$ No liquid waste production

\subsubsection{Comparative Merits of Project and Projection of Future Commercial Economics and Market Acceptabtlity}

The CZD-FGD process is particularly suited for retrofitting onto existing bollers and is not dependent on boiler type, age, size, type of coal burned or sulfur content of the coal. Conventional wet scrubbers for new sources are typically designed to remove $90 \% \mathrm{SO}_{2}$. The CZD-FGD process, however, which only removes $50 \%$ $\mathrm{SO}_{2}$, is more suited to the retrofit market where the emphasis is on the annual reduction of $\mathrm{SO}_{2}$ and minimizing the cost to achieve this annual quota. 
The CZD-FGD technology requires less equipment space requitrements and lower capital and 0\&M costs than conventional systems. The total cost per ton of $\mathrm{SO}_{2}$ removed, including capital and operating costs, is projected to be less than $\$ 300 /$ ton for a 500 MWe unit burning a 4 percent sulfur coal.

\subsection{ENVIRONMENTAL CONSIDERATIONS}

The NEDA compliance procedure, cited in Section 2.2, contains three major elements: a Programmatic Environmental Impact Statement (PEIS); a preselection, project-specific environmental review; and a post-selection, sitespecific environmental document. DOE issued the final PEIS to the public in November 1989 (DOE/EIS-0140). In the PEIS, results derived from the Regiona? Emissions Database and Evaluation System (REDES) were used to estimate the environmental impacts expected to occur in 2010 if each technology were to reach full commercialization, capturing 100 percent of its applicable market. These impacts were compared to the no-action alternative, which assumed continued use of conventional coal technologies through 2010 with new plants using conventional flue gas desulfurization to meet New Source Performance Standards.

The preselection, project-specific environmental review focusing on environmental issues pertinent to decision-making was completed for internal DOE use. The review summarized the strengths and weaknesses of each proposal against the environmental evaluation criteria in the PON. It included, to the extent possible, a discussion of alternative sites and processes reasonably available to the offeror, practical mitigating measures, and a 1ist of required permits. This analysis was provided for consideration of the Source Selection official in the selection of proposals.

As the final element of the NEPA strategy, the Participant (Bechtel Corporation) submitted the environmental information specified in the PON. This detailed site- and project-specific information formed the basis for the NEPA documents prepared by DOE. These documents, prepared in compliance with the Council on Environmental Quality regulations (40 CFR 1500-1508), must be approved before federal funds can be provided for any activity that would limit the choice of reasonable alternatives to the proposed action.

In addition to the NEPA requirements outlined above, the Participant must prepare and submit an Environmental Monitoring Plan (EMP) for the project. The purpose of the EMP is to ensure that sufficient technology, project, and site 
environmental data are collected to provide health, safety, and environmental information for use in subsequent commercial applications of the technology.

The expected performance characteristics and applicable market for confined zone dispersion (CZD) technology were used to estimate the environmental impacts in 2010 which would result from full commerctalization of CZD. The REDES model was used to compare CZD technology impacts to the no-action alternative.

Projected environmental impacts from commercialization of CZD technology into national and regional areas in 2010 are given in Table 1. Negative percentages indicate decreases in emissions or wastes in 2010. Conversely, positive values indicate increases in emissions or wastes. These results should be regarded as approximations of actual impacts.

Table 1.Projected Environmental Impacts in 2010, CZD (Percent Change in Emissions and Solid Wastes)

\begin{tabular}{lccc}
\hline Region & $\begin{array}{c}\text { Sulfur } \\
\text { Dioxides }\end{array}$ & $\begin{array}{c}\text { Nitrogen } \\
\text { Oxides }\end{array}$ & Solid Wastes \\
\hline National & -30 & -6 & +8 \\
Northeast & -39 & -8 & +10 \\
Southeast & -34 & -7 & +9 \\
Northwest & -6 & -2 & +7 \\
Southwest & -16 & -2 & +2 \\
\hline
\end{tabular}

Source: Programnatic Environmental Impact Statement (DOE/EIS-0146) November, 1989.

As shown in Table 1, significant reductions of sulfur dioxide are projected to be achieved nationally due to the capability of the CZD process to remove $50 \%$ of sulfur dioxide emissions from coal-fired botlers and the wide potential applicability of the process. The largest reductions of sulfur dioxide emissions occur in the eastern regions because of the large amount of coal used in the area. The least impact occurs in the Northwest because of the minimal use of coal there. The national quadrants used in this study are depicted in Figure 4. 


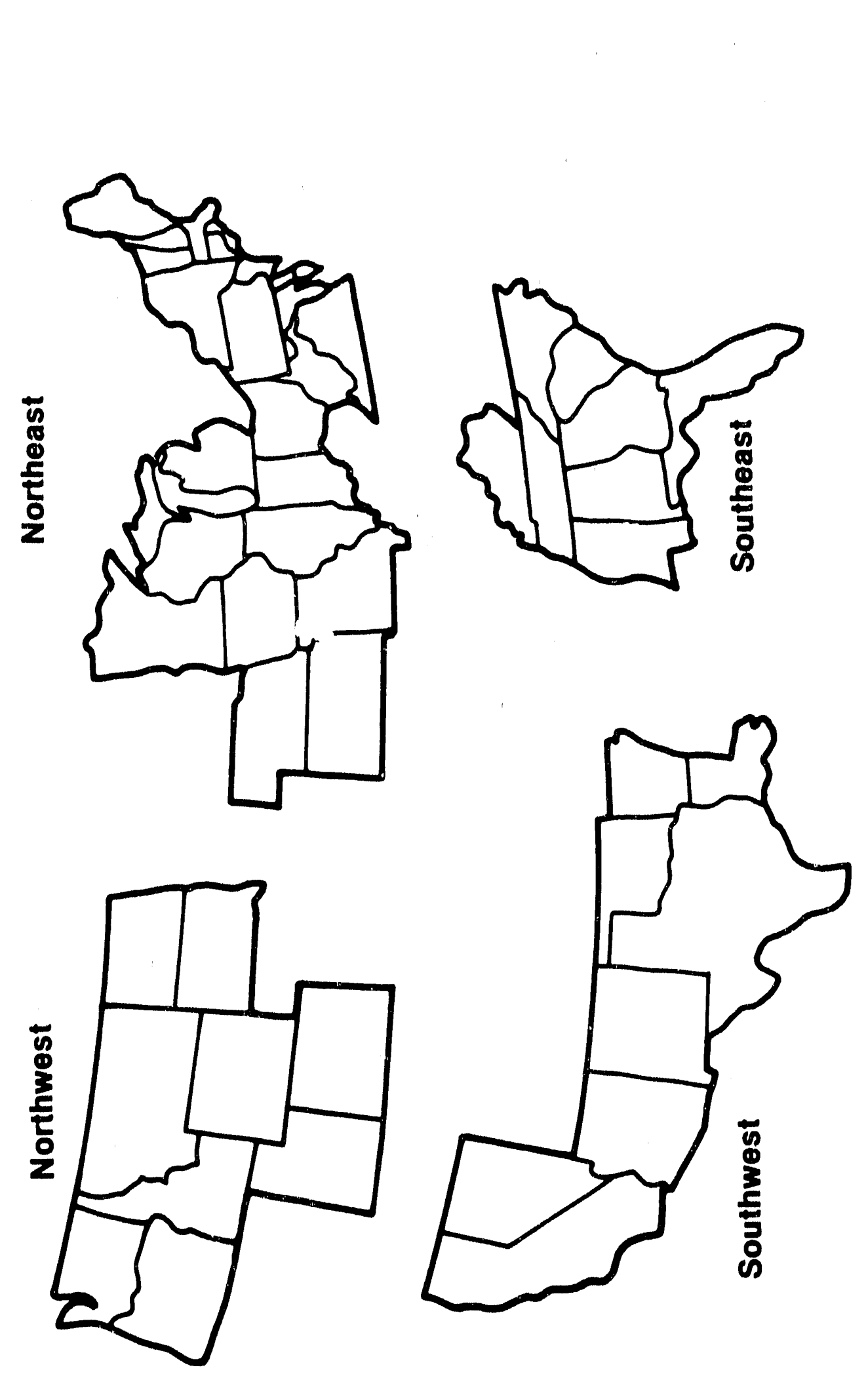

$\underset{\infty}{\infty}$

믈

$\infty$

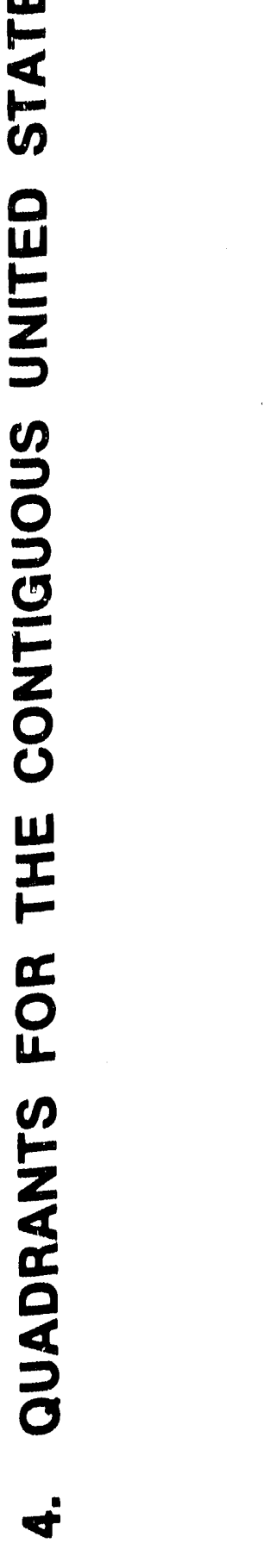

9

0

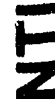

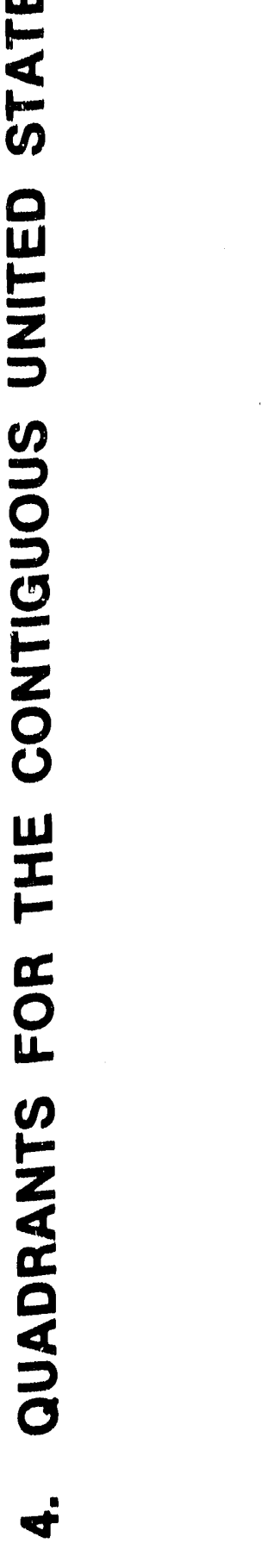

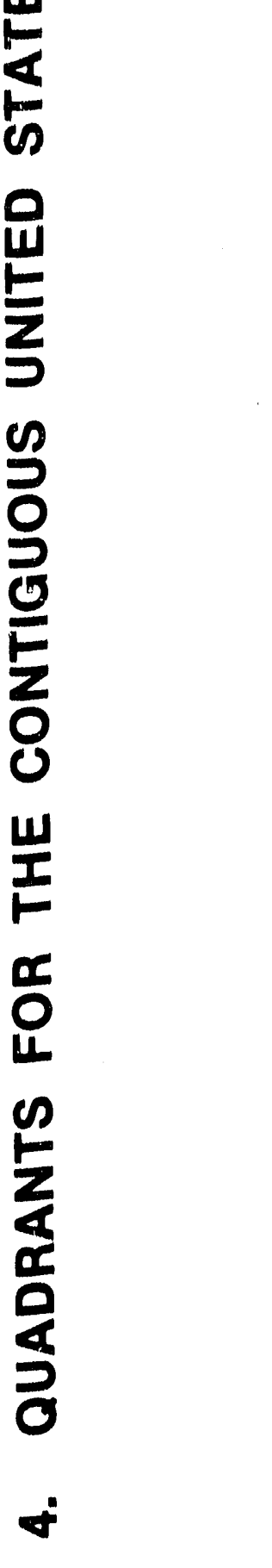

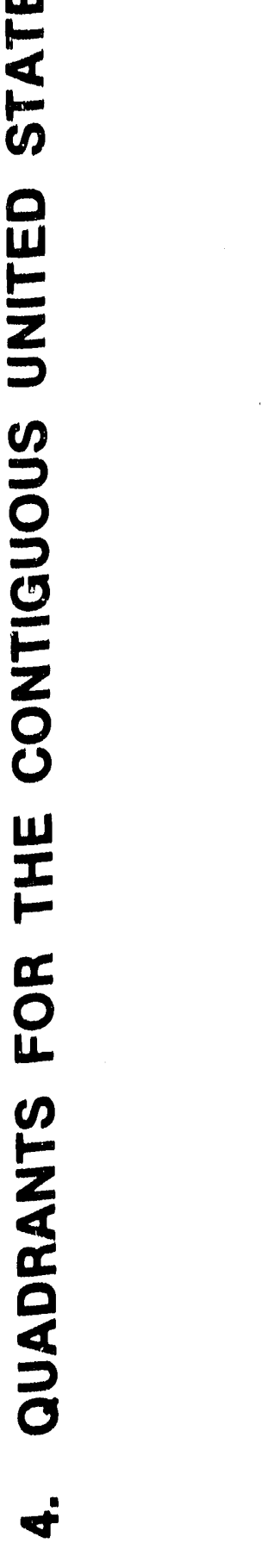

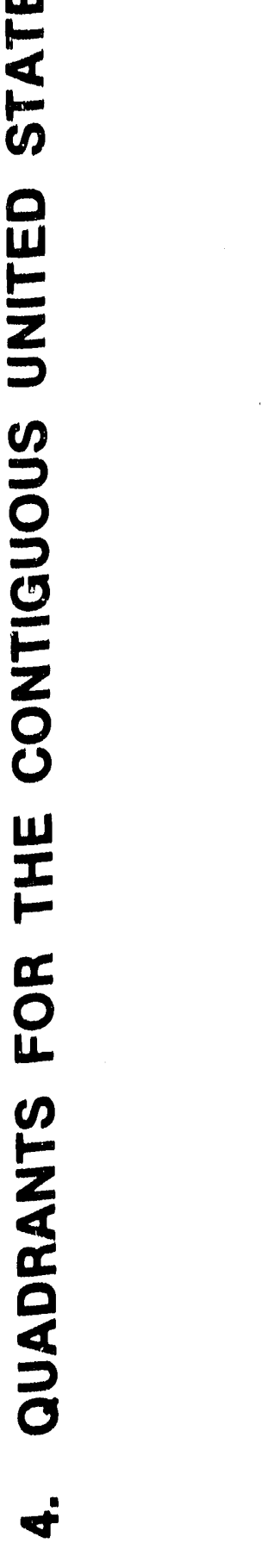

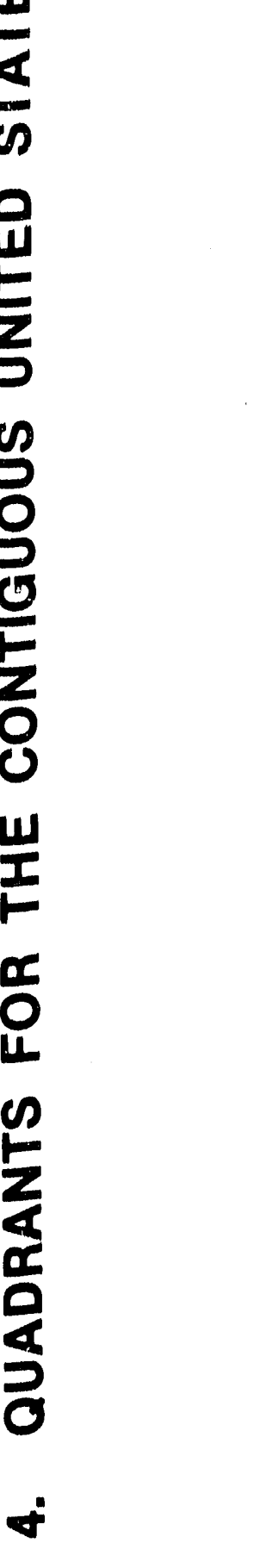

풍

2

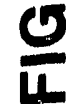




\subsection{PROJECT HANAGEMENT}

\subsection{Over wity of Mana rement Organizition}

The project will be managed by the Participant's (Bechtel's) Project Manager. He will be the principal contact with DOE for matters regarding the administration of the Cooperative Agreement between Bechtel and DOE. The DOE Contracting officer is responsible for all contract matters and the DOE Contracting Officers Technical Representative (COTR) is responsible for technical liatson and monitoring of the project.

A management review committee will be formed and will be composed of personnel from Bechtel's Research and Engineering Organization. Figure 5 shows the project organization for the CZD-FGD demonstration.

\subsection{Identification of Respective Roles and Responsibilities}

$\underline{\mathrm{DOE}}$

The DOE sha11 be responsible for monitoring all aspects of the project and for granting or denying approvals required by the Cooperative Agreement. The DOE Contracting Officer is the authorized representative of the DOE for all matters related to the Cooperative Agreement.

The DOE Contracting Officer will appoint a COTR who will be tine authorized representative for all technical matters and will have the authority to issue "Technical Advice" which may:

$0 \quad$ Suggest redirection of the Cooperative Agreement effort, recommend a shifting of work emphas is between work areas or tasks, and suggest pursuit of certain lines of inquiry which assist in accomplishing the Statement of Work.

- Approve those technical reports, plans, and technical information required to be delivered by the Participant to the DOE under the Cooperative Agreement. 


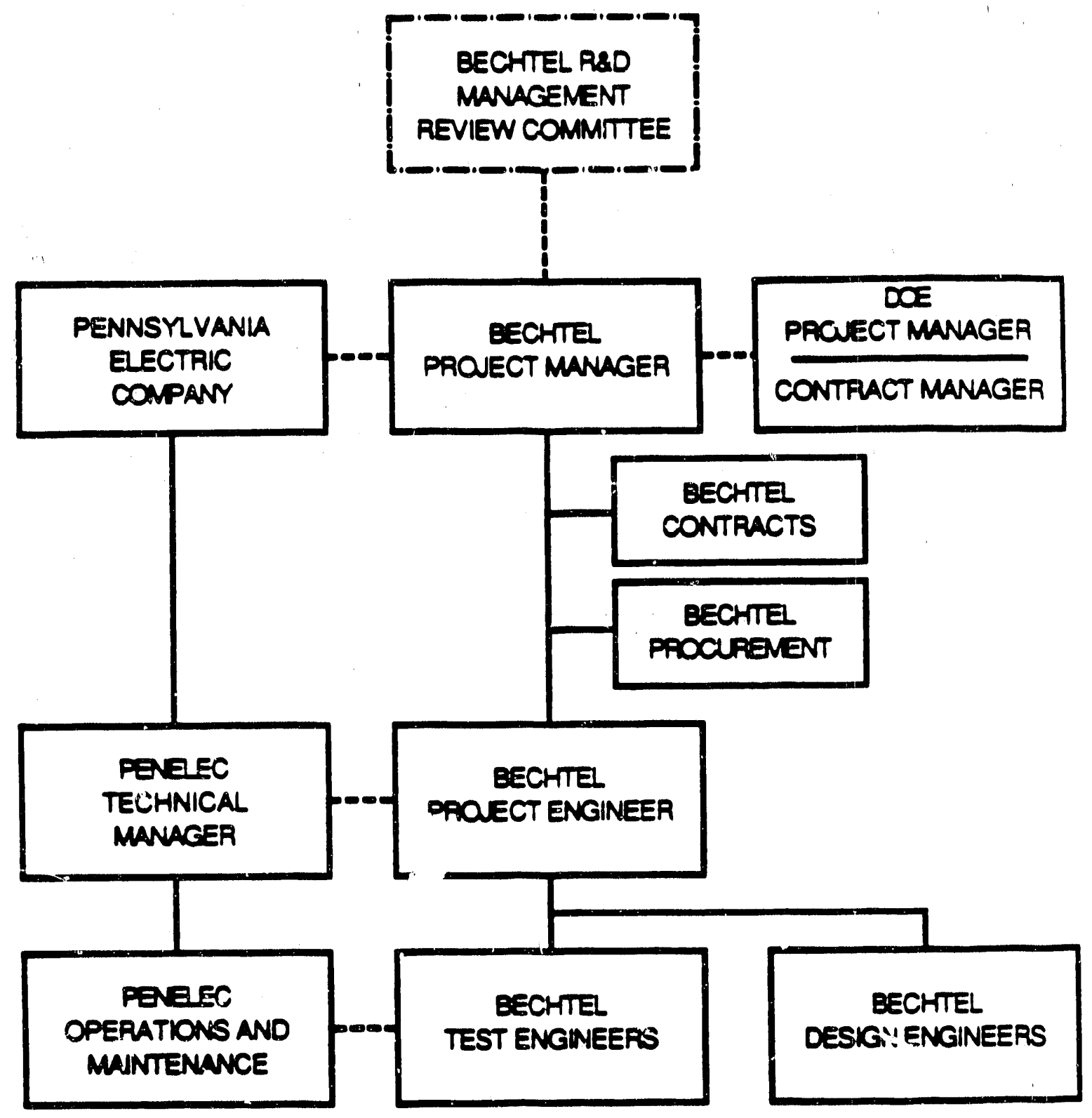

FIGURE 5. PROJECT ORGANIZATION 
The DOE COTR does not have the authority to issue technical advice which:

- Constitutes an assignment of additional r rk ov'side the Statement of Work.

- In any manner causes an increase or decrease in the total estimated cost, or the $t:$ ine required for performance of the Cooperative Agreement.

0 Changes any of the terms, conditions, or specifications of the Cooperative Agreement.

$0 \quad$ Interferes with the Participant's right to perform the terms and conditions of the Cooperative Agreement.

All Technical Advice shall be issued in writing by the DOE COTR.

\section{Participant}

Bechtel will be responsible for all aspects of project performance under the Cooperative Agreement as set forth in the Statement of Work.

Bechte1's Project Manager is the authorized representative for the technical and administrative performance of all work to be performed under the Cooperative Agreement. He will be the single authorized point of contact for all matters between Bechtel and DOE.

The Project Team will also include a Project Engineer. The Project Engineer will report directly to the Project Manager and will be responsible for coordiniting all technical activities at the site during the testing phase of the prosect.

\subsection{Summary of Project Implementation and Control Procedures}

All work to be performed under the Cooperative Agreement is divided into three phases. These phases are:

Phase I: Design and Permitting ( 6 months)

Phase II: Construction and Start-up (6 months)

Phase III: Operation and Disposition (25 months) 
As shown in Figure 6 , the total project encompasses a 37 -month period. There will be no pauses or overlaps between phases.

Two budget periods will be established. Consistent with P.L. 100-446, DOE will obligate sufficient funds to cover its share of the cost for each budget period. Throughout the course of this project, reports dealing with the technical, management, cost and environmental monitoring aspects of the project will be prepared by Bechtel and provided to DOE.

\subsection{Key Agreements Impacting Data Rights, Patent Waivers, and Information Reporting}

Bechtel's incentive to develop this process is to realize retrofit business from, and produce new designs for, the utility and power boiler industry with respect to $\mathrm{SO}_{2}$ abatement technology.

The key agreements in respect to patents and data are:

- Standard data provisions are included, giving the Government the right to have delivered, and use, with unlimited rights, all technical data first produced in the performance of the Agreement.

- Proprietary data, with certain exclusions, may be required to be delivered to the Government. The Government has obtained rights to proprietary data and non-proprietary data sufficient to allow the Government to complete the project if the Participant withdraws.

- A patent waiver may be granted by DOE giving Bechtel ownership of foreground inventions, subject to the march-in rights and U.S. preference found in P.L. 96-517.

- Rights in background patents and background data of Bechtel and all of its subcoritractors are included to assure commercialization of the technology.

Bechtel will make such data, as is applicable and non-proprietary, available to the U.S. DOE, U.S. EPA, other interested agencies, and the public. 


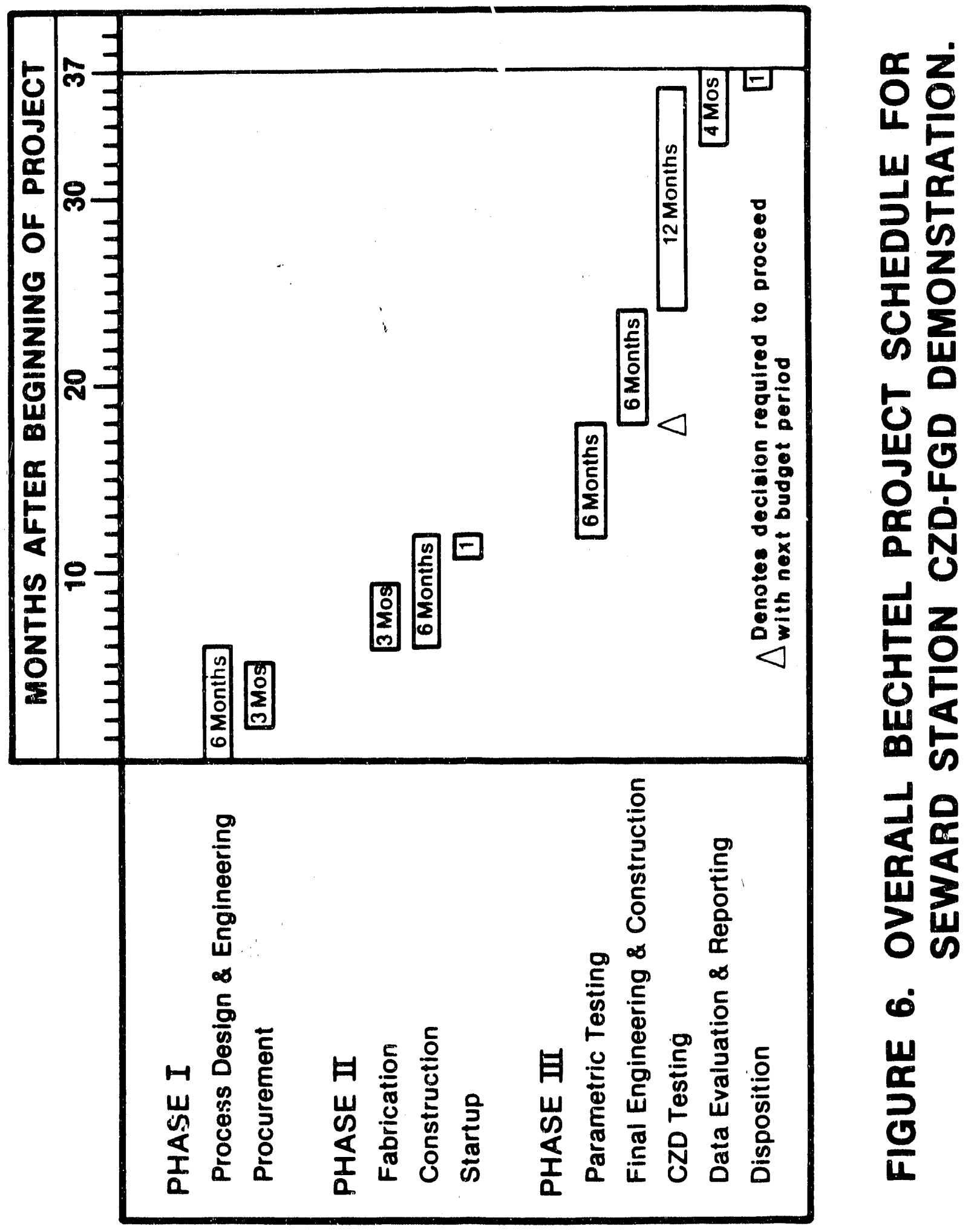




\subsection{Procedures for Commercialization of the Technology}

The CZD-FGD market will be heavily influenced by upcoming acid rain legislation regarding retrofitting of existing coal fired power plants. Bechtel intends to have the CZD-FGD technology ready for full scale commercial application by the early 1990s.

Bechtel's present sales force calls on all domestic utilities. Bechtel presently plans to direct its sales efforts to all potential retrofit sites. For new and retrofit FGD systems, Bechtel will not only license the process, but will design, procure and construct affected facilities. Bechtel will also participate in own/operate arrangements. To recover their investment in emission control facilities, Bechtel will offer, as an option, to process flue gas according to a tolling formula, with unit revenue derived for each ton of $\mathrm{SO}_{2}$ removed.

Bechtel's marketing approach is to provide users with process technologies under a royalty-bearing 1 icense agreement that offers certain performance and/or cost advantages. These are one time paid-up licenses, with the royalty fee based upon the size of the $p l a n t$ and the amount of sulfur reduction required. The fee for the CZD-FGD technology is expected to be in the range of $\$ 1$ to $\$ 3$ per KWe. In return for this royalty, Bechtel will provide the process design and will guarantee $\mathrm{plant}$ throughput and performance. Licensing of the CZD-FGD technology, however, will be on a non-exclusive basis to all clients and they will be free to select their own architect/engineer to perform engineering, procurement, construction and start-up services. Process engineering, however, will still be performed exclusively by Bechtel.

The hardware and shop fabricated components that comprise the process are commercially available and are normally purchased on the domestic open market under conditions of strict competitive bidding. Multiple sources of supply of the various components of the technology are readily available. 


\subsection{PROJECT COST AND EVENT SCHEDULING}

\subsection{Project Baseline Costs}

The total estimated cosit for this project is $\$ 9,211,600$. The Participant's share and the Government's share in the costs of this project are as follows:

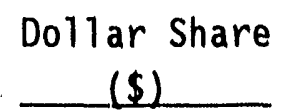

Phase I

Government

Participant

Phase II

Government

Participant

Phase III

Government

Participant

Total Project

Government

Participant

$1,176,350$

275,100

$3,154,350$

$4,605,800$

$4,605,800$
$1,176,350$

$50 \%$

$50 \%$

$50 \%$

$50 \%$

(\%)

$50 \%$

$50 \%$

$50 \%$

$50 \%$

Contributions will be made by the co-funders as follows:

\begin{tabular}{ll} 
DOE & $\$ 4,605,800$ \\
Bechtel & $\$ 761,186$ \\
Penelec & $\$ 2,971,389$ \\
PEDA & $\$ 750,000$ \\
NYSE\&G & $\$ 100,000$ \\
Rockwell Lime & $\$ 23,225$ \\
\hline
\end{tabular}

TOTAL

$50 \%$

$\$ 9,211,600$ 
At the beginning of each budget period, DOE will obligate sufficient funds to pay its share of expenses for that budget period.

\subsection{Milestone Schedule}

The overall project will be completed in 37 months after award of the Cooperative Agreement. The project schedule, by phase and activity is shown in Figure 6.

Phase I, which involves design engineering, permitting and procurement of materials will start immediately after award and continue for six months. Phase II consists of equipment fabrication, construction, and start-up. Phase III, which consists of six months of parametric testing, six months for system automation for continuous operation, one year continuous testing, data analysis, preparation of the final report, and one month for dismantling and disposition, will start upon completion of Phase II and last for twenty-five months. The need for final engineering and construction in Phase III is necessary to adapt the batch operation of 1 ine feed used during parametric testing into a fully automated continuous operation during the one year test period.

\subsection{Repayment P1an}

Based on DOE's recoupment policy as stated in Section 7.4 of the PON, DOE is to recover an amount up to the Government's contribution to the project. The Participant has agreed to repay the Government in accordance with a negotiated Repayment Agreement to be executed at the time of award of the Cooperative Agreement. 

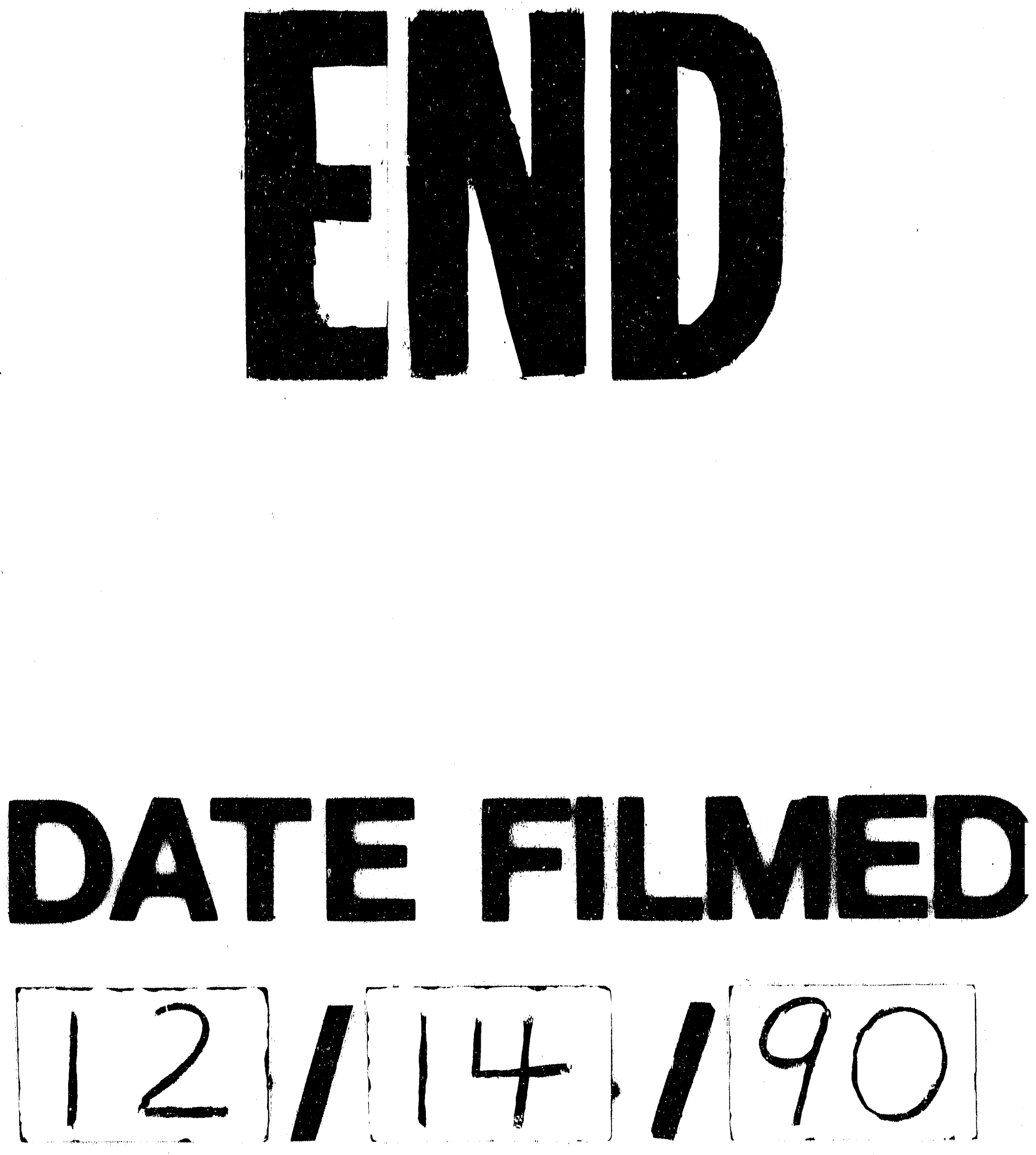
